\author{
J.A. Faulloer, L.C. Vammill, \\ 8.A. Muft1, and B.M. Carloon \\ Departments of Fuyblology and Anatomy \\ Untveratty of Mehtgan Modeal school \\ Ann Arbor, Michigen 48109
}

(Recelved in final form Jume 7, 1976)

\begin{abstract}
Sown
Whole $3 \mathrm{~g}$ extensor afgitorum longue (EDL) muales of cats were eutotranplented. Tbe sDL mecles were olther transplanted without denervation prior to traneplantation (norwal traneplants) or denerrated 3 to 4 rooke prior to tranplantation (pro-denerveted transplante). A fow poriphoral skeletal mucle fibert ourdved transplantation but wost flbers dogenereted and then rogenernted as the traneplant beceme revascularised. Both normal and pro-denervated macles regenernted rucoensfully and by 50 days after trangplentation flbers which had roinnervated ahowed high and low moribrtilar AIPase activity. Corpared to controls, the anliar monn flber crose-esctional area of the transplants was che to the large mber of sall fibere, but some fibers in the transplant wero larger than an rlbers observed in the controls. Tranplents regeined 57 percent of the macle ans of the controls. Contruction and hale relasation timas of trunplanted muscles yere slower than controls,

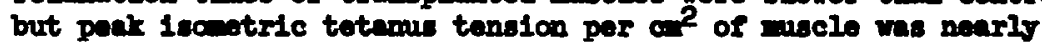
normal. Fifts to 170 daye after tranplentetion, mucles anowed low oxddative capacity and fatiouod rupldiy.
\end{abstract}

Since studitsky and Bosova (13) demonstrated the succesarul free autologous (belonging to the vame organlom) trensplantation of wholo skeletel auscles, survival of tranoplants bave been reported for rats $(3,4)$, cate (7), doge (14), and $\operatorname{man}(6,7,14)$. Controverns still nurrounds the degres of success and the rensons for the nuccess of the akeletal muscle tranoplants. The degree of restorntion of norial structure and function after tranmplantation, the mes. of macle that can be tranoplanted, and the relative percentages of curviving compared to regenoreting miscle flbere are all venresolved questions. The resolution of these controverales is important because ceversl hundred transplantations have been ade for the elinical trentesnt of partial or corplete factal paralyeis $(6,14)$ or for anal incontinence (7). Our purpose was to Investigate the controversial aspecte of skeletal mocle tranopiantation.

\title{
Neterials and yothods
}

Surgery wa perforsed on 32 adult cats $4.2 \pm 0.2$ ig in weight that were froe of disease and that had been maintulnod in the Aninal care Facilities for at least owe wonth. Shrgery was performed with the cats anentheticod by 
letamine $(20 \mathrm{mg} / \mathrm{kg})$ and pentobarbital $(10 \mathrm{mg} / \mathrm{kg})$. Bupplemantal doses wore given as required. Free beterotople auto-tranoplants were made of yhole exteneor difitorum longus (BDI) muscles (nean woight $=3.3 \pm 0.28)^{1}$. The mascles vere tranplanted without denervation prior to traneplantation (normal tranoplants), or with denervation 3 to 4 woeks prlor to transplantetion (predenervited trenplents). The muecle vas denervated by sectioning three branches of the peroneus proprundus norve at the point where each branch entere the mascle. Ho attenpt was ade to prevent re-innorvation but at the time of transplantation etimulation of the norve proximally falled to elfeit contraction of the auscle. This in addition to the lengthened time to peak tension when the pro-denervated mucle was stimlated directly Indicated that these mescles were denervated and had not runctionally re-innervated.

Tranplantation proceeded as follows: The skin was Incleed and the fascia was cut over the rull length of the swl. The muscle was isoleted by severing all nerves and rascular connectlons, as woll as both tendons. Bach EDL was romoved and welghed under sterile conditions. Bech muscle was then plnced into the bed of the contralateral miscle ilth the SDL orfented in the proximaldistal, and medial-lateral aspects as it was in its orfoinal site. Consequently, the wecle was reversed in its doreal-ventral orientation. Both tendons of each transplanted muscle vere autured into place and fascla and akdn were closed by outures. Ito attent was made to mrelceily reesteblish norvous or vescular connections.

The oporated cats were sacriflced between 4 and 170 days after the transplantation. From 4 to 50 days after tranplantation (II = 9), our atudies focused on the hlotological analysis of hentoxylin and cosin (H and B) stainod sections, and from 50 to 170 daye $(\boldsymbol{M}=23)$, on histochemical, blochemical, and contractile property andyses.

At sacriflce, sectlons of each of the 64 transplanted musclos were quick frozen in acetone and dry ice. Ton pm sections were cut and incubated for the activities of succintc acid debydrogenase (8DH) (10), myoribrillar ATPase (5), and capillary membrene phosphatese. Hofibrillar ATPaee reactlone vere perforsed witbout fixation or preincubation. Cepillary membrane phosphatase was performed in the came ndive as wofibrillar ATPuse except that 2.5 mil parmhydroxymercuribenconte was added to inbibit the woribrillar ATPuse. Control and tranoplanted muscles vere incubated in the sum modia. Fibers vere clasalfied as high or low oxldative besed on gpH activity (7) and fast or slow-

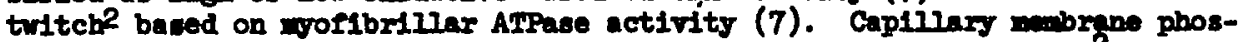
phetese activity was used to count the nuber of capiliaries por diviation of the captliaries per $\mathrm{m}^{2}$ by the muber of skeletel mucle fibers per wo? was defined as the capillary-fiber ratio.

A modifled fales mucle lever (9) was used to sonsure tbe contractile properties of 10 control muclos and 22 traneplanted mucles. EDL muscles were maintained at $300 \mathrm{C}$ and stimulated by direct supra-madmal atimulf. Tho

1. All statiotics include mean $t$ one standard error of the nean.

2. In norwal akoletal mincle motor units, histochenical evidence of high and 10w woflbrillar ATPase has been correlated with the contrectile characteriatica of fast and slow twitch respectively (2). Therefore, we infer the twitch characteristics from the myofibrillar ATPase and use the same terinology as Poter et al. (II). Such correlations have not been made for tranplanted muscle but the transplants show predoninantly high myofibrillar ATPese and the time to peak tension is in the renge of fast-twitch flbers $s 0$ we have chosen to use the sems terms as are used for flbers fron control muscles. 
current Flow during stimutation and the resting macle length vere adjurted to

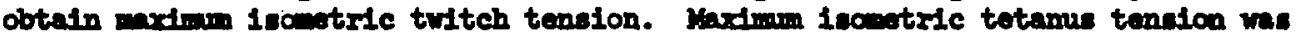
obtelned by increasing the frequency of 2 mbec pulces delfrered during a 90 msec period. Ints brief itiallation perfod ws uned beceuse of the rapid oncet of fatigue in the trenplanted ascles. The fatigability of the control and tranplanted mecles was ectineted by otimulating the muecle with 2 neec pulses, 70 prises per sec, a 200 msec curation, with one stisulation burnt each sec. The time in secs required for the madim iscenetric teterms tension to decrease to $50 \%$ of the inftial value ves used as an entimate of fatigability since longer periods of atimation resulted in a considerable incresse in macie mess due to Iluid abifte (9).

\section{Berulte}

In the hietological section of early tranglants of normel and predenervated mascle, a mall mber of akeletal mixcle flbere just under the wuscle aboath survived the tranplantation process, did not degenorete, and rere ultimately re-innervated. The majority of the mucle flbers degenerated during the first 40 dars and were gredunily replaced by regenerating fibers. The process of degeneration and rogeneration begen junt under the external surface of the mecle (Figure 1) and procesded gramally Imard town the central core of the mecle. The inftiation of deraceration (arreolya1s), the appearance of necrophages, and revascularisation correleted with respect to both time and location vithin the erecle crose section.

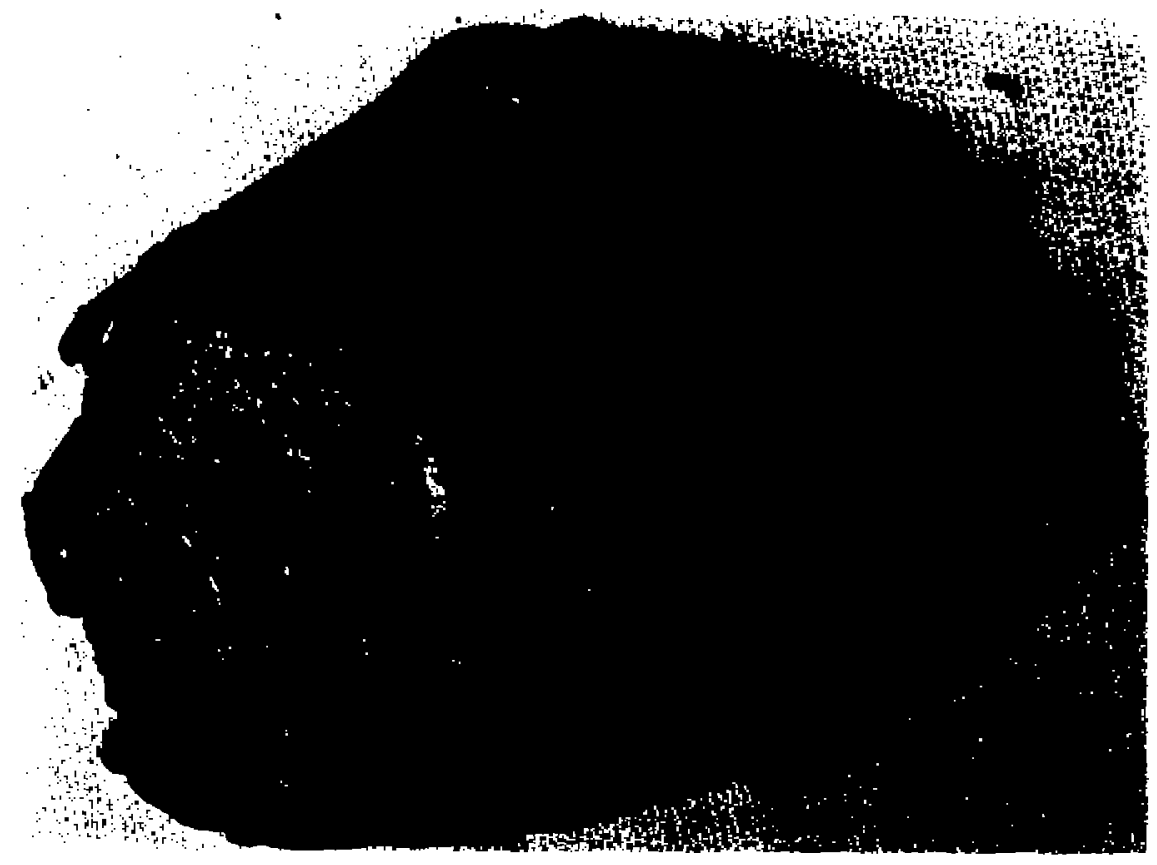

Fir. 1

Crose coction through 8 day tranglant of a cat IDI ansele that had been pre-denerrated for 24 dajt. Inroughout rost of the graft the

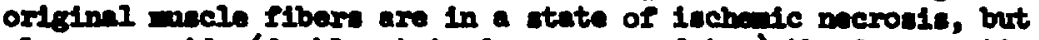
along on side (dartir stalned aree around top) the degeneration of old and the regeneration of now mecle Iibere 1s beginning. (II and I) 
Following tranglantation, orfginal akeletal mecle flbers lost both spH and yroftbriliar ATPase activity as they degenerated, and cap1linary phosphatees activity dieappeared. Between 50 and 170 days folloring tranplantation both pro-donorvatod and normal tranoplants were rovascularized and re-Innerratod. Data on all tranoplanted mascles goteinod during this perlod vere grouped. Figure 2 shows a typical eection of control and trangplantad musclo. In addtion to undifferentiated regenerating flbers, differentiated alow-twitch and fast-twitch fibers were observed (Flgure 21). The low-twitch fibers, which more brondly diepersed in control mascle, were often clustered together in groups in the tranplanted macle (Flgure 2r.). Noan akeletal mascle riber cross-cectional areas wre $2300 \pm 220 \mu \mathrm{m}^{2}$ for control muscles and $1750 \pm 180 \mathrm{um}^{2}$ for tranoplanted muscles. Scme large, as well as muserous small, skelötal muscle flber were seen in the tranplanted muscles (FIgure 2F). These mall flbers may be newly regenerating flbers or non-innorvated flbers that will remain all or atrophy. The tranplanted akeletel ancle flbera showed varying Intencities of 8DH activity (Mgure 2D) but the Intennity ras alvays less than the 8Di activity umally associated with highly oxddative fibers in control mancles (Igure 2A). A blochenical aseay of succinate oxddace ectivity supporte the histochemical observations of reduced orddative capecity. The succinate addase activity of transplanted mascle was $30 \%$ of the control value of 55 $\mathrm{ml} / \mathrm{g} \cdot \mathrm{min}$ at $37^{\circ} \mathrm{C}$. The capillary-Flber ratio (Houre $2 \mathrm{C}, \mathrm{F}$ ) of the tranoplants $(0.89 \pm 0.08)$ was sifonificantly less than that of the controls $(1.75 \pm 0.18)$.

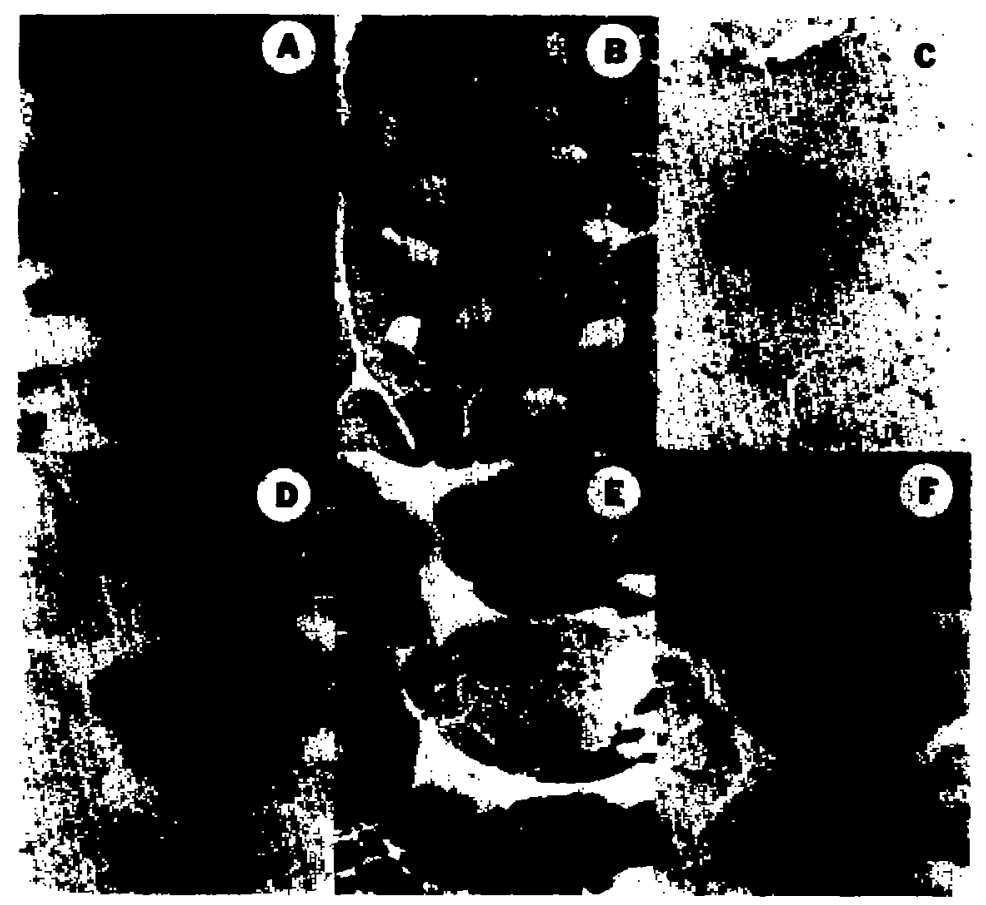

FIt. 2

Typical serial crose-sections of cat control EDL mascle (A, B, C) and I.DL wele 50-170 durs after transplantation (D, E, F) incubated for SDR, woribriline ATPase, and cepillary nowbrane phosphatase activitios pectively. 
In the control EDL muscles, $40 \%$ of the fibers were fast-turitch glycolytic, $44 \%$ fast-twitch oxidative, and $16 \%$ slow-twitch oxidative (Migure 2). This is in ressonable agreenent with previous entimates (1). Trangplants areraged $98 \%$ fast-twitch flbere and the $\mathrm{BDH}$ activity of all fibere mas lon (Flgure 2). The percentage of fast tidtch flbers in the transiants was significantly different $(P<0.05$ ) from controls even though the tranoplants showed considerable variability in composition. Sowe transplants bad a percentage compostion similar to controls (87\% fast-twitch), while others had $100 \%$ fast-twitch fibers.

The control muscles had aximum 1sconotric tetamus tenston of $1.4 \pm 0.1 \mathrm{~kg}$ absolute and the tranoplanted muscles averaged $24 \pm 91$ of that of control muscles. The maximan 1scmetric tetamus tension of both control and transplanted muscles (Figure 3B, D) normalized per $\mathrm{con}^{2}$ of the functional cross-gectional area of the skeletal muecle flbers vas approxdmately 1.5 dynes/cm $2 \times 106$. The value for the transplanted muscles was corrected for their four-fold increase in noncontractile tiseve. Compared to control muscles, the tranoplants took longer to achleve peak 1sonetric tritch tension and had a longer half relaration time (Ploure 3A, C). The capacity of the transplant to shorten (9.6A of the reating length of $9.5 \mathrm{~cm})$, and to exert tension per cr. was only sifightly irpaired. The transplanted muscles fatioued much more rapidiy than the control muscles. With ropeated stimull, the time required for the maximal lecuetric tetame tension to decline to half the Initial value was 162 secs for the controls and 75 secs for the traneplants.
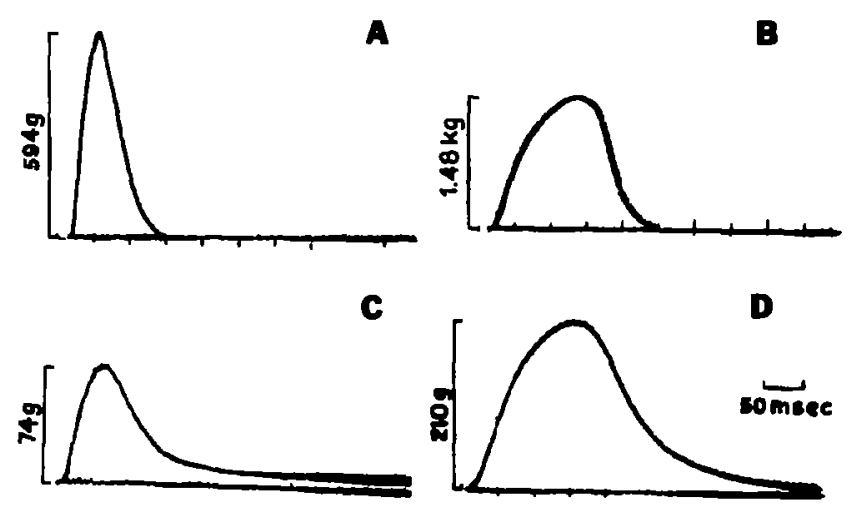

FIO. 3

Besponses of a cat control EDL muscle (A, B) and a 133 day transplanted muele (C, D) during maximum isometric tritch and tetamus reprectively. The muncle weights of $4.7 \mathrm{~g}$ for the control and $1.2 \mathrm{~g}$ for the tranplant vere corrected for velght gain during stimation through multiplication by 0.83 . The 50 meec marter record 1s for all 4 records. 
Although the time course of the bletological changes following transplantation was more rapid in the pre-denervated transplants than in the normol transplants, a comparison of the muscles 50 to 170 days after tranplantation abowed fer significant differonces. The moans for norial tranplants and the pre-denorvated tranplants respectivaly were 1.8 and $1.9 \mathrm{~g}$ for the mass of the tranmlant, 98 and 98 for percentage of fast-twitch fibers, 200 and $251 \mathrm{~g}$ for absolute naximal 1nometric tetanus tension, and 10.5 and 9.2 for percentage shortening. Fone of these differences vere significant $(P<0.05)$.

\section{Diacussion}

Early transplants of cat miscles, both normal and pro-denervated, followed a sequence of bletological changes sintlar to those observed in the rat $(3,4)$ but the time course was different. Bvents cheracteristic of the firat 5-6 days in the transplanted IDL rexcle of the rat were extendod over 6-7 weeks in the cat.

A mall muber of surviving akeletal muscle ribere in the periphery of the tranplant was typical of tranoplants of ruts (2) and cats. Thees peripberel fibers appear to obtain sufficient oxygen and mutrients by diffunton to nurvive until revascularizetion occurred. Contrary to the asmumption that murvivil of okeletal muscle fibers contributes to the succese of transiantation in cats (8), dogs (14), and man (14), the majority of the wucle ribers in the tranopint degenerated and then regenerated. Nost variables showed a sinflar tim coures of degeneration and regeneration. This consists of approdinately 35 days of degeneration followed by a credual restoration of structure and runction. Fone of the variables reached non-denervated, non-tranoplanted control values by 170 days. Although the rate was slower, the histological resctions in the Ear mescle of the cat were sinilar to those reported for the cat peroneous longus arcle (12). The process of degenoration and rogenerntion secind to dopend on revescularisation since sections of tranoplants that did not revaccularise romained as a mass of connective and necrotic muecle tissue.

Previous reports auggest that only pre-denervated mucles tranplant succeastully $(6,8,14)$, however, in our material, skeletal wascle flbera regenerated ruccessully in both pro-donervated and normel transplents. Ime degenerative and regenerative processes occur more rapidly in pre-denervated transplants but by 50 days there were few differences between the two types of transplants. We are unable to explein the exphasis $(6,8,14)$ that bas been placed on the noed to predenarvate auccles prior to the tim of tranplantation.

The slower time to peak tension and $\frac{1}{2}$ relaxation time of the trenglants compared to the controls are not conal ctent with the higher percentage of fasttwitch fibers or with the contractile properties of long tes tranplants in rats. In rats (4), the time to paek tenston returns to noriel, but the half relaxation time remains somenhat elowe. This way be a function of the increased amounts of connoctive tigere in the grafts. 8ince notor unite are composed of onls one fiber type (2) the grouping together of elor-triteh flbers (type grouping) in come tranplants ouggents a clustering of the fibers of com notor units. Such cluntering is not observed in control mucles.

The gradual increase in BDH activity and the bupertroph of como aleselal auclo Hibors indicates that the tranopianted wasole is used. Both sDil activity and the resistance to fatigue unully correlate directly with the frequenoy of

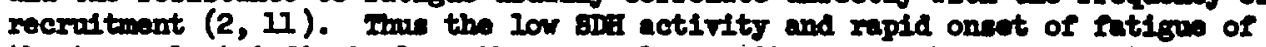
the tranplant indicate lose than normal recruitenent of what appeare to be a viable tranoplant. 


\section{Acinowledgemonts}

Inis study was apported by grante from the suscular Dyatrophy Asecciation of Amorica, Inc. and by a Muccular Dystrophy Portdoctorel Fellowhip to shahrad A. Mufti.

\section{Beferences}

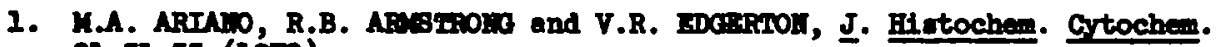
21 51-55 (1973).

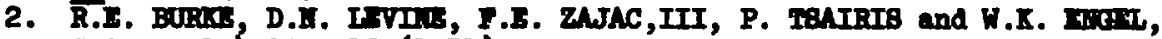
Sctence 174 709-712 (1971).

3. B.M. CARTSOIN and E. GUMNUL, Anat. Rac. 183 47-62 (1975).

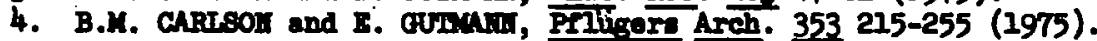

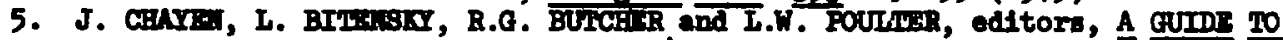

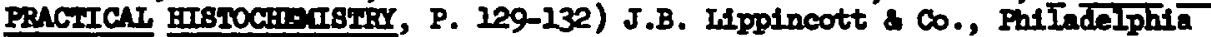
(1972).

6. L. BAKLITUB, Bcan. J. Plant. Beconstr. Burg. 8 220-230 (1974).

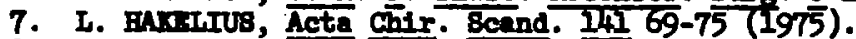

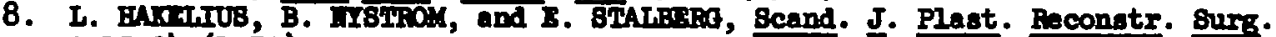
2 15-24 (1975).

9. R.A. MARPH and A.C. BEARDSIEY, Am. J. Fhveiol. 227 1008-1018 (1974).

10. M. IACHAS, K.X. TSOU, E. DE SOUZA, C. CHLAT and A.M. BELIGEMH, J. B1etochen. Grtochem. I2 740-743 (1964).

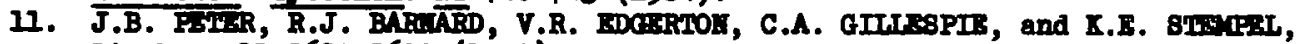
Biochen. II $2627-2633$ (1972).

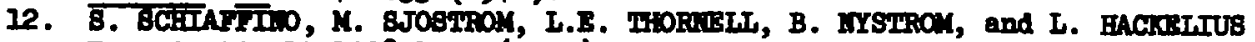
Experientia 15 1328-1330 (1975).

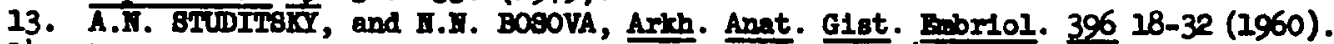

14. 1. THOMPSOH, Plastic and Reconotx. Burx. 48 17-27 (1971). 